\title{
Penatalaksanaan Karies Rampan dengan Evaluasi Menggunakan Kario- gram: Laporan Kasus pada Anak dengan Self-Mutilation
}

\section{Diah A. Purbaningrum}

Departmen Kedokteran Gigi Fakultas Kedokteran Universitas Diponegoro, Semarang, Jawa Tengah, Indonesia

Email: diahajeng88@gmail.com

\begin{abstract}
To date, rampant caries has still a high prevalence. Evaluation of caries can be carried out comprehensively in patients with rampant caries by using a cariogram which can describe the causes and risks of caries. We reported a case of a girl aged 4 years, complaining of swelling of the back part of her lower gum. The patient was diagnosed as self-mutilation by a pediatrician. There were some scars in her left forefinger and wrist. Moreover, her teeth 51, 61, 72,71 , and 81 were loose. Clinical examination revealed poor oral hygiene, abscesses in the teeth 74 and 75 , and many dental caries as well as tooth radixes. The patients had bottle feeding until the age of 3 years. Cariogram was performed at the first visit, followed by dental health education (DHE) and topical application of fluoride. Cariogram evaluation was carried out at the first visit, the 3rd month, and the 6th month, resulting in 15\%, 19\%, and 35\% in prediction of preventing new caries, respectively. The patient was treated with cariogram follow-up, total care with block system, DHE, and topical application of fluoride. In this case, there was an increased prediction of caries prevention, and a decreased caries risk factors including diet and bacteria.
\end{abstract}

Keywords: rampant caries, cariogram, caries management

\begin{abstract}
Abstrak: Sampai saat ini karies rampan masih memiliki prevalensi yang tinggi. Penilaian karies dilakukan secara komprehensif pada pasien dengan karies rampan dengan menggunakan kariogram yang dapat menggambarkan penyebab dan urutan risiko karies. Kami melaporkan kasus seorang anak perempuan berusia 4 tahun dengan keluhan gusi belakang kiri bawah bengkak. Pasien didiagnosis oleh dokter spesialis anak menderita self mutilation. Terdapat bekas luka pada jari telunjuk kiri, pergelangan tangan, dan gigi 51,61, 72, 71, 81 sudah tanggal. Pemeriksaan klinis menunjukkan oral hygene buruk dengan abses pada gigi 74 dan 75, banyak terdapat karies dan radiks. Pasien memiliki kebiasaan minum susu botol dengan dot sampai usia 3 tahun. Kariogram dilakukan pada kunjungan awal, diikuti edukasi kesehatan gigi dan mulut (DHE) dan pemberian topikal aplikasi fluor (TAF). Evaluasi dengan menggunakan kariogram dilakukan pada awal kunjungan, bulan ketiga dan bulan keenam dengan hasil kemungkinan menghindari karies baru sebesar 15\%, 19\% dan 35\% secara berturut. Penatalaksanaan kasus ini ialah dengan follow-up kariogram, total care dengan sistem blok, DHE, dan TAF. Pada kasus ini terjadi peningkatan kemungkinan menghindari karies baru yang cukup tinggi dan terjadi penurunan besarnya faktor risiko karies pada faktor pola diet dan bakteri.
\end{abstract}

Kata kunci: karies rampan, kariogram, penatalakasanaan

\section{PENDAHULUAN}

Karies gigi masih banyak dijumpai di Indonesia. Prevalensi karies pada anak sekolah dasar hampir 60-80\%, sedangkan di Amerika Serikat 93\% dari populasi mempunyai lesi karies. ${ }^{1}$ Karies rampan merupakan terminologi yang dipakai untuk menjelaskan karies dentis yang muncul tiba-tiba, lalu secara cepat menghasilkan suatu lubang, mengakibatkan keterlibatan awal dari pulpa dan memengaruhi gigi-gigi yang biasanya kebal terhadap karies. 
Karies ditandai adanya demineralisasi jaringan keras gigi yang diikuti oleh kerusakan bahan organiknya. Etiologi karies ialah multifaktor. Karies dapat terjadi karena adanya interaksi antara pejamu, makanan/substrat, bakteri, dan waktu. ${ }^{2}$ Karies dapat mengenai gigi sulung dan gigi tetap, tetapi proses kerusakan gigi sulung lebih cepat menyebar, meluas, dan lebih parah dibandingkan gigi tetap. Faktor penyebab adanya perbedaan ini ialah karena struktur email gigi sulung kurang padat dan lebih tipis dibandingkan gigi tetap, morfologinya lebih tidak beraturan, dan kontak antar gigi merupakan kontak bidang. ${ }^{3}$

Karies rampan merupakan salah satu masalah kesehatan gigi yang paling parah dan sering terjadi pada anak. ${ }^{4}$ Karies terjadi dengan tiba-tiba, mengenai banyak gigi dalam waktu singkat, dan cepat melibatkan pulpa. Karakteristik karies ini ialah dimulai dengan terkenanya permukaan gigi anterior rahang atas dan semakin berkembang ke posterior, sehingga yang lebih parah terkenanya proksimal gigi insisivus bawah hingga ke bagian servikal. ${ }^{1}$ Anak yang menderita karies rampan berisiko tinggi untuk perkembangan karies di masa datang sehingga perlu dilakukan pemeriksaan aktivitas bakteri karies agar usaha pencegahan karies dapat lebih ditingkatkan. ${ }^{5}$

Penanganan karies rampan harus dilakukan secara komprehensif dengan tujuan utamanya ialah menghentikan proses karies atau sekurang-kurangnya mengurangi aktivitas karies. Kebiasaan pemberian susu pada malam hari dianjurkan untuk dihentikan secara bertahap atau mengganti pemberian susu dengan air putih atau minuman bebas gula. Penggunaan fluor dan rutinitas menyikat gigi untuk menghilangkan plak juga penting dalam perawatan. ${ }^{6}$ Mengurangi kebiasaan buruk, mengubah pola makan, pemberian produk antibakteri, aplikasi fluoridea restorasi gigi yang karies, dan bila perlu dilakukan ekstraksi. Pemberian nasihat dan informasi tentang karies rampan kepada orang tua sangat penting serta eliminasi kebiasaan buruk minum dari susu botol dapat diperoleh dengan cara mengurangi jumlah gula pada susu dengan menambah jumlah air. Kegiatan ini dapat dilakukan dalam beberapa minggu. ${ }^{7}$

Penilaian risiko karies sangat penting dilakukan dalam penanganan komprehensif pada pasien dengan karies rampan. Penilaian tersebut dapat dilakukan pada awal perawatan dan sepanjang perawatan berjalan dengan tujuan untuk mengevaluasi keberhasilan perawatan. ${ }^{8}$ Penilaian risiko karies ini dapat menggunakan kariogram yaitu suatu alat ukur berupa software komputer yang dapat digunakan untuk menilai risiko karies di klinik gigi. Kariogram dapat menganalisis data seperti riwayat karies, penyakit yang berhubungan dengan karies, jenis dan jumlah asupan makanan yang biasa dikonsumsi (diet), jumlah plak, Streptococcus mutans (flora normal mulut), aktivitas fluor, sekresi saliva, dan kapasitas buffer dari saliva. ${ }^{9}$ Mengingat masih tingginya prevalensi karies rampan dan dampaknya pada anak maka penulis terdorong untuk mendeskripsikan evaluasi perawatan karies rampan dengan menampilkan laporan kasus pada seorang anak berusia 4 tahun dengan menggunakan evaluasi kariogram.

\section{LAPORAN KASUS}

Seorang anak perempuan berusia 4 tahun datang dengan keluhan gusi belakang kiri bawah bengkak. Anak didiagnosis oleh seorang dokter spesialis anak menderita self mutilation (Gambar 1). Terdapat bekas luka pada jari, pergelangan tangan (Gambar 2 dan 3) dan gigi 51, 61, 72, 71, dan 81 sudah tanggal (Gambar 4). Pemeriksaan klinis menunjukkan oral hygene buruk dengan abses pada gigi 74 dan 75, karies gigi $52,53,54,62,63$, dan 84 , serta radiks gigi 64 dan 65 (Gambar 5 dan 6). Pasien memiliki kebiasaan minum susu dalam botol dengan dot sampai usia 3 tahun. Pasien pernah dibawa ke dokter gigi, tetapi tidak kembali control lagi. Radiografi panoramik memperlihatkan pada gigi 74 dan 75 tampak area radiolusen hingga kedalaman pulpa; gigi 52, 53, 54, 62, 63, 84 tampak area radiolusen hingga kedalaman dentin; gigi 64 dan 85 tampak radiks serta tidak adanya benih gigi 15, 25, 45 (Gambar 7). 


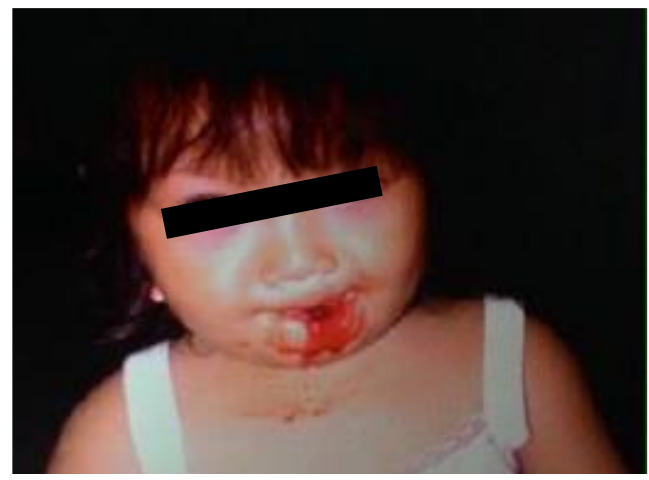

Gambar 1. Pasien dengan self-mutilation

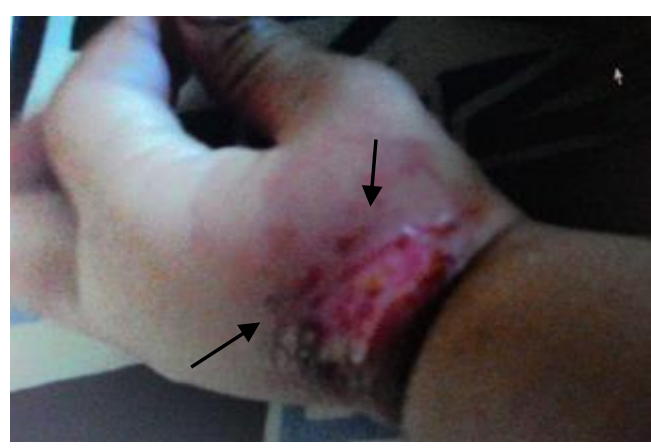

Gambar 3. Luka bekas gigitan pada pergelangan tangan

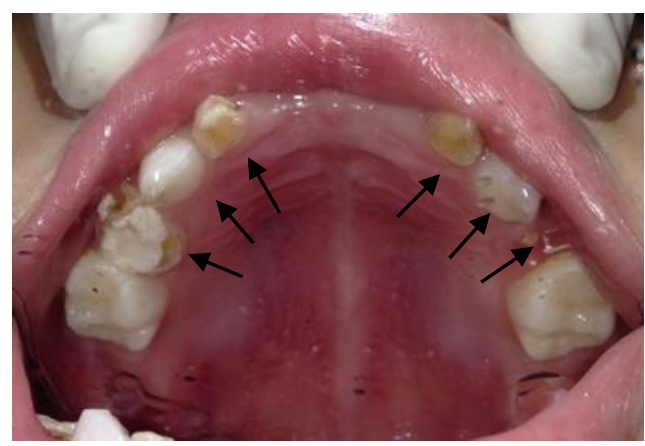

Gambar 5. Sisa radiks dan gigi karies pada rahang atas

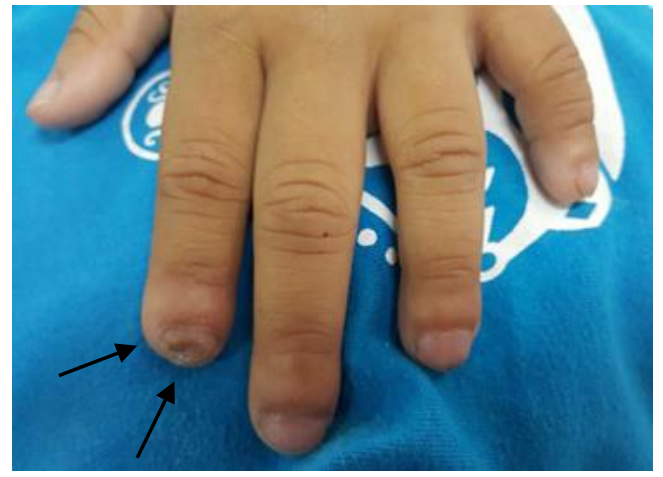

Gambar 2. Bekas gigitan

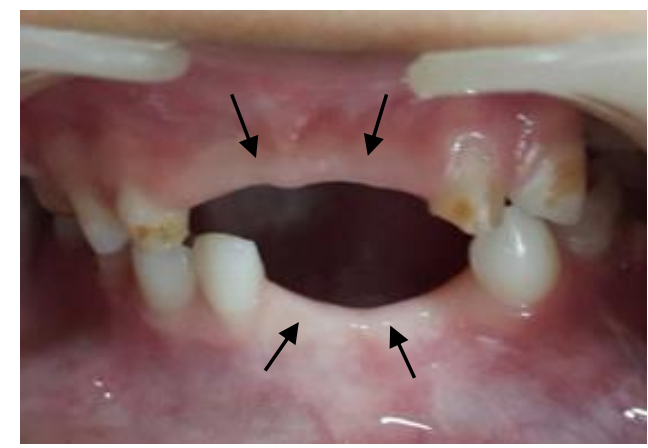

Gambar 4. Gigi anterior rahang atas dan rahang bawah yang tanggal sebelum waktunya

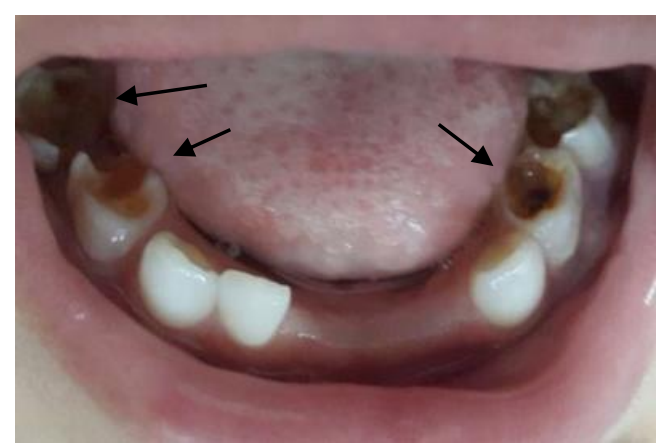

Gambar 6. Sisa radiks dan gigi karies pada rahang bawah

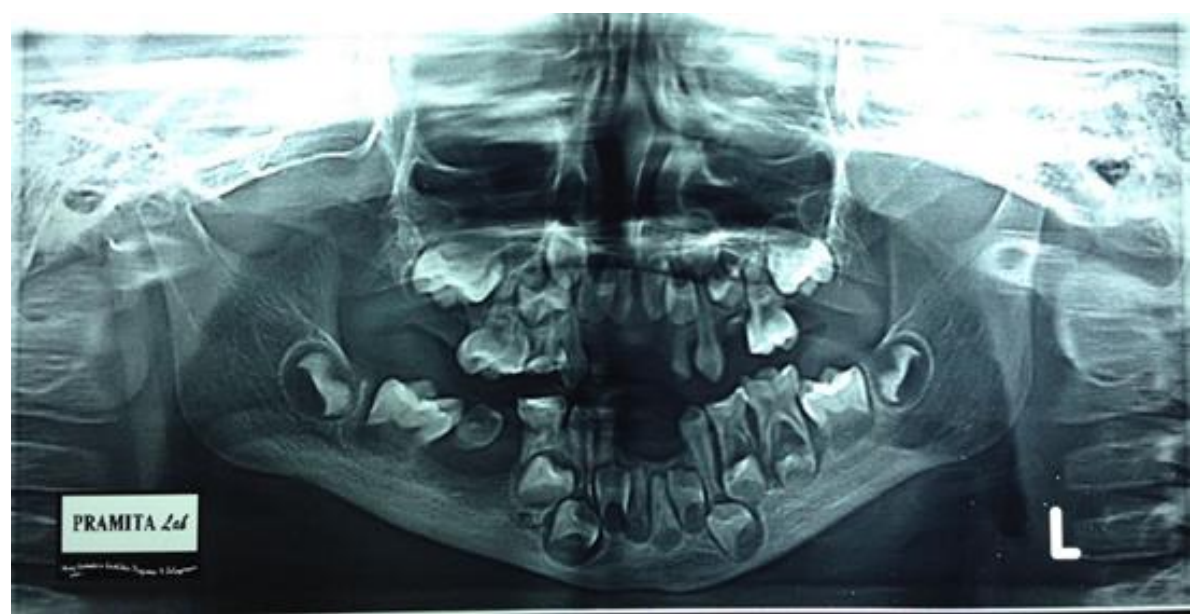

Gambar 7. Radiografi panoramik. 
Pada awal kunjungan dilakukan penilaian risiko karies menggunakan kariogram. Edukasi tentang kesehatan gigi diberikan kepada pasien dan orang tua. Edukasi yang diberikan berupa frekuensi dan cara menggosok gigi yang benar, serta diperagakan cara menggosok gigi yang benar. Pada kunjungan pertama orang tua diberikan lembar survei diet tahap I dan instruksi mengenai cara pengisian. Hasil kariogram dari kunjungan pertama menunjukkan kemungkinan untuk menghindari karies baru $15 \%$ dengan faktor karies seperti pola makan 30\%, bakteri $24 \%$, kerentanan $18 \%$, dan keadaan 12\% (Gambar 8). Berdasarkan hasil ini diberikan rekomendasi untuk menganjurkan orangtua agar mengawasi pola makan anak yang banyak mengandung gula, memberikan makanan yang banyak serat seperti sayur dan buah-buahan, mengurangi konsumsi makanan dan minuman manis dan lengket, serta mengurangi konsumsi makanan yang kariogenik. Selain itu juga dianjurkan kepada orangtua dan anak untuk memperhatikan dan menjaga kebersihan mulut dengan cara menyikat gigi sedikitnya dua kali sehari, yaitu setelah sarapan pagi, dan sebelum tidur dengan pasta gigi yang mengandung fluor dan aplikasi topikal fluor.

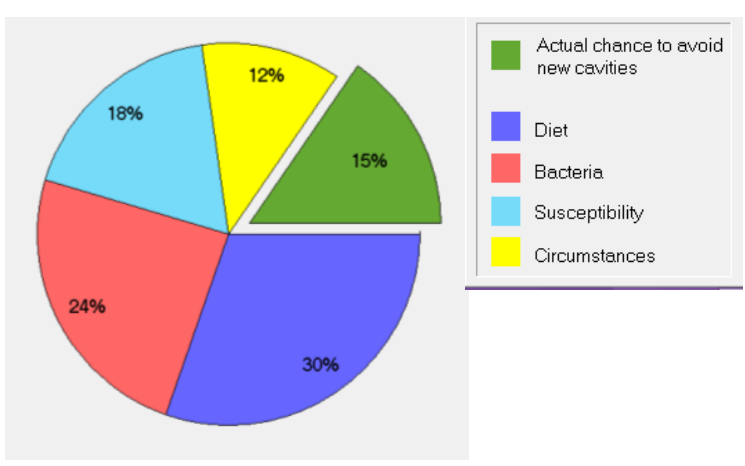

Gambar 8. Kariogram tahap I

Pada awal kunjungan dilakukan perkenalan dengan pasien dan orangtua pasien dengan membangun kepercayaan dan menciptakan rasa aman pada anak dan orang tua melalui komunikasi verbal dan non verbal. Hal ini dilakukan agar perawatan gigi dapat dilakukan dengan lancar, dilanjutkan dengan pemeriksaan awal keadaan ekstraoral dan intraoral, kemudian dilakukan dental health education (DHE), plak skor, dan pemeriksaan bakteri dengan kariostat. Setelah pasien merasa aman maka dilakukan trepanasi karena berkaitan dengan keluhan utama pasien.

Pada kunjungan kedua, sebelum tindakan anak diberi penjelasan dan cara penggunaan file endodontic. Perawatan endodontik dilakukan dengan ekstirpasi pulpa dan preparasi saluran akar kemudian dilanjutkan dengan sterilisasi saluran akar menggunakan $\mathrm{CaOH}$ dan gliserin. Penumpatan gigi 53, 52, 62, dan 63 dengan menggunakan glass ionomer cement (GIC) juga dilakukan pada kunjungan kedua.

Pada kunjungan ketiga, pasien kembali untuk dilakukan perawatan endodontik dan pencabutan gigi. Anak diberi penjelasan dan dikenalkan dengan anestesi topikal Pada perawatan hari ketiga dilakukan penggantian dressing dengan $\mathrm{CaOH}$ dan gliserin, dilanjutkan penumpatan gigi 84 dan pembuatan stainless steel crown (SSC) gigi 54 dan ekstraksi pada gigi 74 .

Pada kunjungan keempat dilanjutkan perawatan endodontik untuk obturasi dengan metapex, ditumpat dengan cavit, dan ekstraksi gigi 64 dengan infiltrasi.

Pada kunjungan kelima, dilakukan penumpatan pada gigi 74 dan 75, serta pencetakan rahang atas dan rahang bawah untuk pembuatan protesa. Pada kunjungan keenam dilakukan insersi protesa rahang atas dan rahang bawah (Gambar 9 dan 10).

Pada bulan evaluasi ketiga, restorasi masih baik. Evaluasi risiko karies ditegakkan kembali menggunakan kariogram, yang menunjukkan kemungkinan menghindari karies baru sebesar 19\% (Gambar 11). Hal tersebut berarti telah terjadi peningkatan 4\% dibandingkan kunjungan pertama. Faktor risiko karies terbesar ialah pola makan yaitu $34 \%$, bakteri $20 \%$, kerentanan $14 \%$, dan keadaan $13 \%$. Edukasi kesehatan gigi dilakukan lagi kepada pasien dan orang tuanya untuk terus mengurangi permen, makanan atau minuman yang manis dan mengandung karbohidrat tinggi. Pasien terus dimotivasi untuk menjaga kebersihan gigi dan mulutnya. 


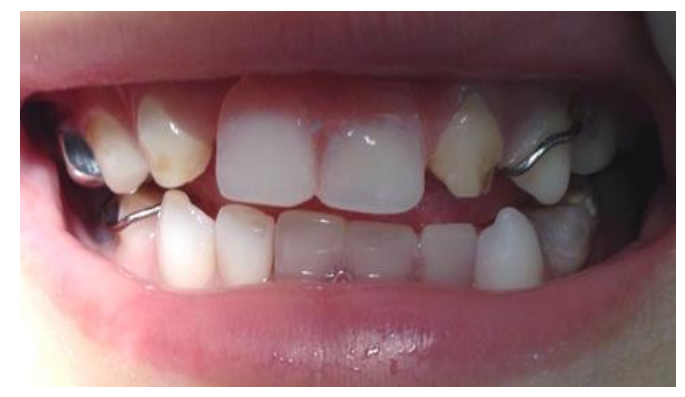

Gambar 9. Tampak depan setelah perawatan

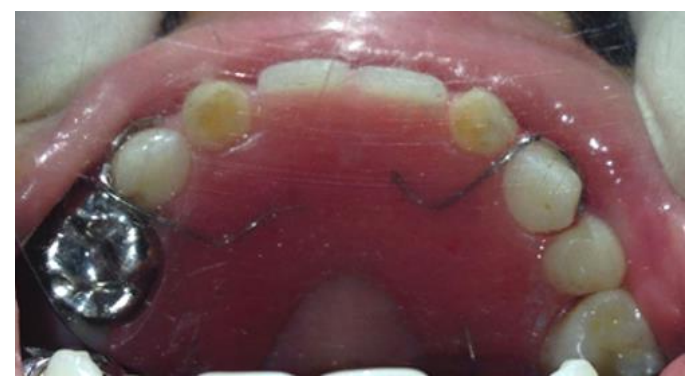

Gambar 10. Tampak oklusal rahang atas setelah perawatan

Selain itu, dilakukan motivasi pasien agar mengunjungi dokter gigi secara berkala untuk membersihkan plak dan debris, dan perawatan gigi bila ada tumpatan gigi yang lepas, serta gigi yang luksasi atau persistensi.

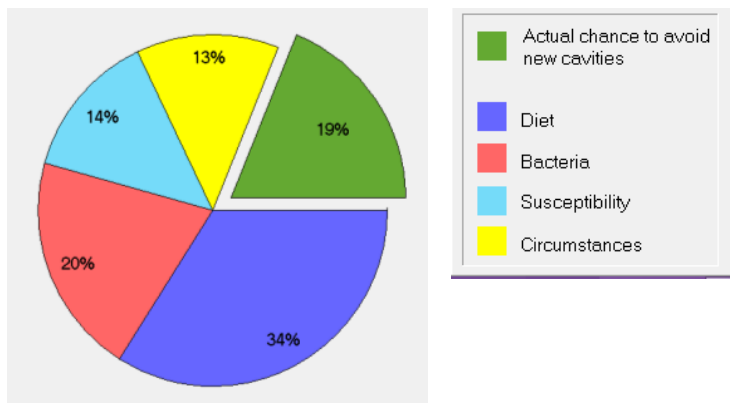

Gambar 11. Kariogram tahap II

Pada bulan evaluasi keenam, restorasi masih bagus. Evaluasi risiko karies ditegakkan kembali menggunakan kariogram dengan hasil yang menunjukkan kemungkinan menghindari karies baru sebesar $35 \%$. Hal tersebut menunjukkan terjadi peningkatan sebesar $16 \%$ jika dibandingkan dengan kunjungan kedua. Faktor pola makan mengalami penurunan yaitu menjadi $33 \%$, bakteri $13 \%$, kerentanan $7 \%$, dan keadaan 13\% (Gambar 12). Edukasi kese- hatan gigi kembali dilakukan dengan menganjurkan untuk terus memperbaiki pola makan, yaitu menghindari makanan dan minuman yang mengandung karbohidrat tinggi, dan mengonsumsi banyak makanan yang berserat, seperti sayur dan buahbuahan. Pasien dianjurkan untuk banyak mengonsumsi air putih setelah makan, dan dimotivasi terus untuk menjaga kebersihan gigi dan mulutnya dengan menyikat gigi dua kali sehari, serta mengingatkan kontrol ke dokter gigi secara berkala untuk membersihkan plak dan debris. Kontrol untuk perawatan dilakukan bila ada tumpatan yang lepas atau ada gigi yang luksasi.

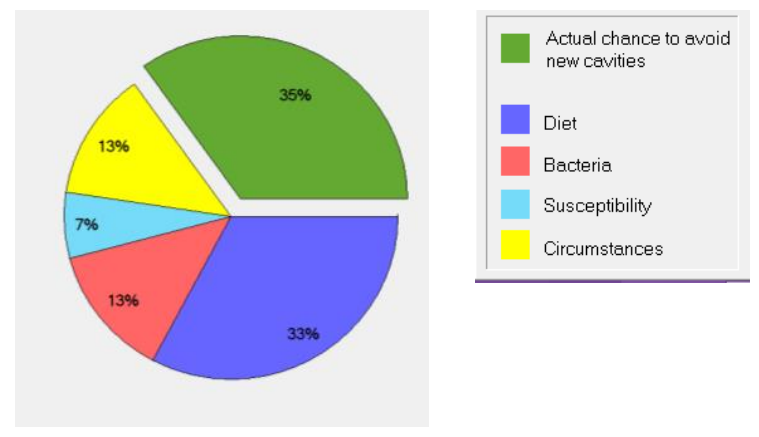

Gambar 12. Kariogram tahap III

\section{BAHASAN}

Karies gigi pada anak banyak disebabkan karena konsumsi susu botol yang dikenal sebagai karies rampan. Karies rampan merupakan karies yang terjadi dengan tiba-tiba, melibatkan banyak gigi dalam waktu singkat termasuk gigi anterior bawah yang biasanya imun terhadap karies serta cepat melibatkan pulpa sehingga merupakan kondisi yang meyulitkan bagi pasien anak, orang tua dan anak. ${ }^{1}$ Oleh karena itu diperlukan upaya untuk menurunkan kejadian karies melalui upaya promotif dan pencegahan.

Dalam upaya pencegahan karies, kariogram dapat digunakan untuk menghitung kemungkinan tidak terjadinya kavitas. Dari parameter yang digunakan dapat diketahui risiko terjadinya karies yang dinyatakan dalam persentase. Kariogram memresentasikan besarnya pengaruh tiap faktor risiko 
terhadap pembentukan karies gigi. Hal ini dapat membantu pasien dalam pencegahan terbentuknya kavitas baru. Parameter kariogram meliputi diet, bakteri, kerentanan, dan lingkungan. Faktor yang meningkatkan risiko karies disimbolkan dengan warna tertentu yaitu hijau, biru tua, merah, biru muda, dan kuning. Warna hijau menunjukkan persentase estimasi kesempatan untuk menghindari pembentukan kavitas baru. Diet yang dimaksud ialah frekuensi dan banyaknya kandungan gula yang biasa dikonsumsi, ditunjukkan dengan warna biru tua. Unsur bakteri menentukan kematangan plak dan jumlah Streptococcus mutans yang diukur dengan indeks plak dan aktivitas bakteri yang tumbuh setelah dibiakkan dalam media kultur, ditunjukkan dengan warna merah. Unsur kerentanan gigi menjelaskan kemampuan daya tahan gigi terhadap karies yang diukur melalui jumlah kerusakan gigi karena penyakit periodontal dan penyakit periodontal yang permah diderita, ditunjukkan dengan warna biru muda. Unsur lingkungan atau kondisi individu menjelaskan peran program fluoridasi, kecepatan sekeresi saliva dan kapasitas buffer saliva. Warna kuning menunjukkan keadaan berdasar riwayat karies sebelumnya, dan penyakit lainnya yang terkait.

Pada kasus ini, penilaian risiko karies menggunakan kariogram dilakukan sebanyak 3 kali, yaitu 1 kali sebelum dilakukan perawatan, dan 2 kali setelah perawatan (evaluasi 3 dan 6 bulan). Hasil kariogram sebelum dilakukan perawatan menunjukkan kemungkinan untuk menghindari karies baru $15 \%$ dengan faktor karies seperti pola makan $30 \%$, bakteri $24 \%$, kerentanan $18 \%$ dan keadaan $12 \%$. Berdasarkan hasil ini diberi rekomendasi untuk menganjurkan kepada orangtua agar mengawasi pola makan anak yang banyak mengandung gula, dan memberikan makanan yang banyak serat seperti sayur dan buahbuahan, mengurangi konsumsi makanan dan minuman manis dan lengket, serta mengurangi konsumsi makanan yang kariogenik. Selain itu juga dianjurkan kepada orangtua dan anak untuk memper- hatikan dan menjaga kebersihan mulut dengan cara menyikat gigi sedikitnya dua kali sehari, yaitu setelah sarapan pagi, dan sebelum tidur dengan pasta gigi yang mengandung fluor dan aplikasi apikal fluor.

Pada evaluasi bulan ketiga, kemungkinan menghindari karies meningkat menjadi $19 \%$. Hal ini dikarenakan oleh penurunan faktor risiko. Penurunan faktor risiko tertinggi terjadi pada faktor bakteri. Hal ini dapat disebabkan oleh aplikasi fluorida topikal dan kemampuan pasien untuk menjaga kebersihan mulut lebih baik setelah edukasi kesehatan gigi, sedangkan untuk faktor diet justru mengalami peningkatan sebanyak 4\%. Hal ini kemungkinan disebabkan pasien yang belum dapat mempertahankan dietnya dengan baik, meskipun edukasi kesehatan gigi dan mulut telah diberikan untuk mengurangi konsumsi makanan ringan dan minuman yang manis. Pasien masih memiliki kebiasaan untuk mengonsumsi makanan ringan manis di antara waktu makan. Perubahan kebiasaan pada anak dalam perilaku makan membutuhkan waktu yang lama. Konsumsi makanan ringan atau minuman yang manis di antara waktu makan dapat meningkatkan risiko karies. Pasien kemudian diinstruksikan lagi untuk selalu membersihkan gigi dan mulut dengan pasta gigi yang mengandung fluorida.

Evaluasi bulan keenam menunjukkan peningkatan untuk menghindari terjadinya karies baru sebesar $16 \%$ dan terjadi penurunan faktor risiko pola makan dan bakteri. Penurunan faktor risiko pola makan hanya sedikit terjadi karena pasien masih belum bisa mempertahankan dietnya dengan baik. Selain itu, menurut orang tuanya, pasien tidak suka mengonsumsi buah dan sayur yang diperlukan untuk mencegah karies.

Penatalaksanaan karies rampan pada kasus ini ialah dengan follow-up kariogram, total care dengan sistem blok, DHE, dan topical application of fluoride (TAF). Total care dilakukan dengan sistem blok untuk mempermudah menentukan perawatan yang harus segera dilakukan dan mempermudah penanganan pasien berdasarkan kunjungan. Pada seluruh karies gigi 
dilakukan penumpatan dengan menggunakan GIC yang bertujuan untuk mencegah karies karena efek GIC yang mengandung fluor, dan untuk karies yang sudah lebar dibuatkan stainless steel crown (SSC). Gigi yang sudah tidak dapat dipertahankan berupa sisa akar diekstraksi dan untuk menjaga ruang erupsi gigi permanen khususnya untuk gigi posterior maka dibuatkan protesa yang sekaligus berfungsi sebagai space maintainer.

\section{SIMPULAN}

Kami melaporkan kasus seorang anak perempuan berusia 4 tahun dengan karies rampan dan self-mutilation. Penatalaksanaan pada kasus ini ialah dengan follow-up kariogram, total care dengan sistem blok, dental health education, dan topical application of fluoride. Pada kasus ini terjadi peningkatan kemungkinan menghindari karies baru yang cukup tinggi dan terjadi penurunan besarnya faktor risiko karies pada faktor pola diet dan bakteri.

\section{Konflik Kepentingan}

Penulis menyatakan tidak terdapat konflik kepentingan dalam studi ini

\section{DAFTAR PUSTAKA}

1. McDonald RE, Avery DR, Dean JA. Treatment of deep caries, vital pulp exposure, and pulpless teeth. In: Dentistry for the Child and Adolescent (7th ed). St Louis: Mosby, 2004; p. 413-39.

2. Kidd EMM, Bechal SJ. Dasar-dasar Karies Penyakit dan Penanggulangannya,
Jakarta: EGC, 1993.

3. Soesilo D, Santoso ER, Diyatri I. Peranan surbitol dalam mempertahankan kestabilan saliva pada proses pencegahan karies. Dental Jurnal. 2005;38(1):25-6

4. Hattab FN, Al-Omari MAO, Angmar-Mansson B, Daoud N. 1999, The prevalence of nursing caries in one-to-four year old children in Jordan. J Dent.Child. 1999; 66(1):53-8.

5. Mathewson RJ, Primosch RE. Fundamentals of Pediatric Dentistry (3rd ed). Chicago: Quintessence Publishing Co Inc, 1995; p.79-82.

6. Koch G, Poulsen S. Pediatric Dentistry a Clinical Approach (1st ed)., Copenhagen: Munksgaard, 2001; p. 189-92.

7. Drummond B, Kilpatrick N, Bryant R, Lucas J, Hallet K, Silva M, et al. 2003, Dental caries and restorative paediatric dentistry. In: Cameron AC, Widmer RP, editors. Handbook of Pediatric Dentistry (2nd ed). London: Mosby-Wolfe, 2003; p. 44-68.

8. American Academy of Pediatric Dentistry. Definition of early childhood caries. 2008. Available from: https://www. google.com/search?q=8.+American+ Academy+of+Pediatric+Dentistry.+Def inition+of+early+childhood+caries. +20 $08 \&$ oq $=8 .+$ American + Academy + of $+\mathrm{P}$ ediatric+Dentistry.+Definition+of+earl $\mathrm{y}+$ childhood+caries. $+2008 \&$ aqs $=$ chro me..69i57.1551j0j7\&sourceid=chrome \&ie $=$ UTF- 8

9. Anup N, Cariogram VP. A multi-factorial risk assessment software for risk prediction of dental caries. Int J Sci Study. 2014; 1(4):58-6. 